\title{
Mobile Phone Apps for Behavioral Interventions for At-Risk Drinkers in Australia: Literature Review
}

Carol C Choo ${ }^{1}$, DPsych (Clin); André A D Burton², MCouns

${ }^{1}$ College of Healthcare Sciences, James Cook University, Singapore, Singapore

${ }^{2}$ School of Psychology, Murdoch University, Perth, Australia

Corresponding Author:

Carol C Choo, DPsych (Clin)

College of Healthcare Sciences

James Cook University

149 Sims Drive

Singapore, 387380

Singapore

Phone: 6567093760

Fax: 6567093889

Email: carol.choo@jcu.edu.au

\section{Abstract}

Background: The mobile technology era has ushered in the use of mobile phone apps for behavioral intervention for at-risk drinkers.

Objective: Our objective was to review recent research relevant to mobile phone apps that can be used for behavioral intervention for at-risk drinkers in Australia.

Methods: The inclusion criteria for this review were articles published in peer-reviewed journals from 2001 to 2017 with use of the search terms "smartphone application," "alcohol," "substance," "behavioural intervention," "electronic health," and "mobile health."

Results: In total, we identified 103 abstracts, screened 90 articles, and assessed 50 full-text articles that fit the inclusion criteria for eligibility. We included 19 articles in this review.

Conclusions: This review highlighted the paucity of evidence-based and empirically validated research into effective mobile phone apps that can be used for behavioral interventions with at-risk drinkers in Australia.

(JMIR Mhealth Uhealth 2018;6(2):e18) doi: 10.2196/mhealth.6832

\section{KEYWORDS}

problem drinking; alcohol drinking; eHealth; telemedicine; smartphone; mobile applications; behavioral intervention; risk reduction behavior; review

\section{Introduction}

In Australia, alcohol is a common substance of dependence for which individuals seek treatment [1]. Reducing the risk of alcohol-related harm is important in Australia, with a government that takes a harm minimization approach [2-4]. The preferred approach for alcohol interventions in Australia has been to prevent the adverse consequences associated with alcohol consumption rather than banning drinking altogether [5]. Psychological interventions informed by the stages of change model [6,7], as well as therapeutic techniques from motivational interviewing [8], cognitive behavioral approaches [9], and self-management strategies [8,10], hold promise to change problematic behaviors [7,11] and address adverse consequences related to drinking [12].

In recent decades, the advent of mobile phone technology has transformed the mode of delivery of psychological treatment [13]. Through promotion of the accessibility of interventions via mobile phone apps, alcohol dependence interventions may be enhanced and the adverse consequences of risky drinking may be reduced [6]. The demand for electronic health apps across Australia and the world is mirroring larger societal trends wherein consumer acceptance of technology has grown [14,15]. Community interest has increased in Australia regarding the use of mobile phone apps to address substance abuse [16], health monitoring, and self-management [17]. Some clinics in Australia 
have implemented conjunctive treatment modalities in guided programs such as cognitive behavioral therapy and psychoeducation apps alongside face-to-face therapy sessions [17]; for example, the DBT Diary Card \& Skills Coach [18] was designed as an adjunctive tool to therapy for individuals recovering from substance abuse. However, research examining its effectiveness lacked conclusive evidence due to the lack of distinction made between the different types of substance use $[19,20]$.

Our aim was to review research relating to the evidence for mobile phone apps that can be used for behavioral intervention for at-risk drinkers in Australia.

The literature positions mobile phone apps under the umbrella of mobile health and its subcategory electronic health, which is defined as health care practice supported by electronic processes and communication [21]. For this review, smartphone refers to a mobile phone that performs many of the functions of a computer. This typically includes having a touchscreen interface, Internet access, and an operating system capable of running downloaded apps. A mobile app is a computer program designed to run on mobile devices such as smartphones and tablet computers. It allows for third parties to design software and apps that can then be downloaded by the user at their discretion.

At-risk drinker is defined as a heavy drinker who consumes 5 or more drinks on the same occasion on each of 5 days or more in the past 30 days [22]. In contrast to a binge drinker, who has a pattern of drinking that brings blood alcohol concentrations up rapidly after consuming alcohol in one go, an at-risk drinker displays consistency in their heavy drinking levels.

\section{Methods}

The inclusion criteria for this review were publication in peer-reviewed journals from 2001 to 2017 with use of the search terms "smartphone application," "alcohol," "substance," "behavioural intervention," "electronic health," and "mobile health." The databases we searched were PsycINFO, Scopus, Google Scholar, and PubMed.

We initially used the PsycINFO database to identify peer-reviewed articles with the inclusion criteria named above; this yielded 11 results. The Scopus database search yielded 19 articles. We then conducted hand searches: a backward search using the reference lists of relevant articles and a forward search that checked publications from authors who had cited these relevant articles. The backward and forward searches generated 11 more articles. The focus was on recently published articles in peer-reviewed journals that fit the inclusion criteria and were relevant to a mobile phone app that could be used for behavioral intervention for at-risk drinkers in Australia.

We retrieved articles if they related to interventions provided via a mobile phone app for at-risk drinkers. The strategy for evaluating eligibility for inclusion involved the following: recent articles that contained original work published in peer-reviewed journals after the year 2001; and articles related to use of a mobile phone app by clinicians for therapeutic purposes. We excluded articles that did not refer to the use of mobile phone apps by clinicians for therapeutic purposes.

\section{Results}

A total of 103 articles satisfied all inclusion criteria in the original search across all the databases. Of the original 103 search results, we screened 90 articles, after which we assessed 50 full-text articles against the inclusion and exclusion criteria, and then deemed 19 of these to be suitable for inclusion in this review [17,23-40]. Multimedia Appendix 1 presents the results of the review.

Overall, the articles show a lack of convincing evidence of effective mobile phone apps that can be used for behavioral intervention for at-risk drinkers in Australia. Randomized controlled trials did not yield significant results on the primary outcome $[23,24]$. Other studies were limited by small sample sizes [25,26] or only reviewed mobile phone apps [27] and did not specifically address our research question [17] of whether the mobile phone app was effective for behavioral intervention for at-risk drinkers in Australia. Although qualitative studies are not typically included in a systematic review, we decided to include these in our table (Multimedia Appendix 1) to illustrate the state of research in Australia, that convincing evidence is still lacking. A study in Australia conducted by Weaver and colleagues [26] reviewed available mobile phone apps and then used a qualitative methodology of focus groups, which offers preliminary exploration. However, it does not offer evidence for their use within the demographic group most at risk for developing alcohol problems in Australia, namely men aged 20 to 29 years and indigenous youths [22,41], who often develop dysfunctional drinking habits that maintain their dependence [42]. Risky drinking in younger demographics is known to be a risk factor for suicidality [43] and other adverse mental health outcomes.

\section{Discussion}

As younger demographics are more likely to access online information relating to mental health problems [44-46], mobile technologies can enhance patient-centered care for youths and young adults in an increasingly technology-savvy society [28], highlighting a growing need to offer electronic interventions as an adjunctive tool to face-to-face therapy $[47,48]$. Evidence for the use of mobile phone apps has been demonstrated in many other areas [49-54] but not for at-risk drinking in Australia. Internet-based interventions have been found to be efficacious for mental health issues [3] in young adults [45,47,55]. Behavioral monitoring apps have been used for mental health interventions $[29,56]$ in addition to face-to-face therapy. Positive outcomes were shown in overall motivation [57], and in maintaining and reinforcing behavioral changes [16,57,58]. These apps show promise for use with ethnically diverse and low-income populations [59] to enhance support [17], help them to cope, and aid in recovery $[60,61]$. Behavioral data can be quantified into graphs [56] and used by clinicians [29,62]. However, youths view apps as a form of entertainment rather than therapeutic tools [26]. The focus could be shifted with an emphasis on behavioral modification instead [63] and apps 
could be used as an adjunctive tool to complement face-to-face therapy delivered by qualified health professionals $[2,15,64]$. More research is needed to support the effectiveness of such apps for use with indigenous youths and young adults in Australia.

Mobile phone interventions have been used for drinking problems in a few clinics in the United States [29] but with less compelling evidence for clinics in Australia. Behavioral monitoring apps are being used for digital behavior change interventions that provide goal setting and behavior monitoring [30], which also allow for triggers to be detected. The AlcoDroid Alcohol Tracker [65] allows for tracking alcohol consumption, as does the Alcohol Tracker [66]. Most of these apps are based on simple features that estimate the amount of alcohol in the blood [67-70], which could be used to set specific drinking targets but do not constitute the most important element for the monitoring of risky drinking [26].

Despite a large increase in research on electronic interventions in recent years (refer to Multimedia Appendix 1), gaps in knowledge remain. Specifically, there is a lack of strong evidence examining the efficacy of mobile phone apps that have been empirically validated with rigorous scientific methods for at-risk drinkers in Australia, especially young males [4,29] and indigenous youths. Youths can be impressionable consumers, and principles of rigorous scientific inquiry should be applied to explore the benefits of the use of health-related apps in this population [71]. Research aimed at examining low-cost mobile phone apps that are efficacious as an adjunctive tool to therapy would add significantly to the literature [29]. Considering the prevalence of alcohol problems [22], especially in young males and indigenous youths in Australia, research is much needed to explore alternative ways to deliver effective interventions [72]

It is important to understand that any therapy or medical treatment has the potential to cause harm, and that any device can cause adverse effects if used incorrectly. Some critiques of the mobile phone app movement have focused on the ethical importance of protecting consumers from potential harm. There should be laws and regulations [73] governing the operation of mobile phone app stores, and steps should be made available to legislators to protect consumers. This argument follows that if apps were to be used in health care settings for therapy, it is important that the stores be reputable and that the apps be created by legitimate third-party software developers [73]; for example, iTunes App Store currently contains 20,000 apps in the Medical category, yet it is not clear what is precisely relevant for clinical decision making with specific at-risk groups [31].

The critical issue for clinicians using mobile phone apps with their patients is the risk to benefit ratio with such a large selection of apps [73]. During this fledgling stage of exploration when apps are yet to be rigorously assessed and curated formally based on their content, clinicians should carefully consider safety issues. In Australia, it is a prerequisite in the Therapeutic Goods Act [74] for health apps to ensure data security and that all claims made regarding the app comply with the Australian consumer law that they are not misleading the consumer [74]. No apps in Australia fall under the label of medical device, which requires registration under the Therapeutic Goods Act [74]. If apps could be registered as medical devices, perspectives toward privacy may change, since data security would be mandated as a part of the registration [75]. This would also allow regulatory action to be followed through if there were legal issues that needed attention.

There is concern over accessibility in terms of limitations of digital cover in remote communities [75,76]. A difference in network coverage and affordability of the type of mobile phones that can be used to host the app may disadvantage Australians who already experience significant socioeconomic disadvantage and who are also at risk of higher rates of alcohol use [77]. Additionally, a critique has been made on whether youths could become somewhat dependent on apps [78]. However, problem drinkers or those at risk of alcohol addiction are not a homogeneous group, and this must be considered when clinicians are deciding on app suitability for use with their patients. The needs of the patient need to be carefully considered.

In summary, there is consensus that alcohol misuse is a widespread problem in Australia [79]. The health and social consequences resulting from the misuse of alcohol have been widely reported $[32,80]$. Reducing the risk of alcohol-related harm is important for affected individuals and society at large $[2,3]$. Enhancing the delivery of interventions may reduce the adverse consequences of alcohol misuse [6]. The potential use of mobile phone apps in the delivery of behavioral interventions tailored for at-risk drinkers remains promising, but evidence to support their use is lacking in Australia. More research is needed to address the gaps in knowledge and to provide an evidence base for the implementation of mobile phone technologies. Developing mobile tools for young users with substance and alcohol abuse issues requires careful ethical consideration regarding the patient-practitioner relationship, the logic of self-surveillance, and overall best practice.

More rigorous research and evaluations are needed to ascertain the efficacy of and establish evidence for best practice for use of such mobile phone apps [17]. The real-time delivery of interventions aimed at reducing risky drinking holds promise to support people who are seeking to change their behavior [32]. Although drinking apps do exist, there are many inconsistencies in their features [26]. Apps that are designed specifically for behavioral interventions for at-risk drinking have not been empirically studied in Australia. Quality and ethical issues relating to the use of such technology need to be considered on a deeper level.

\section{Acknowledgments}

Administrative support and publication cost for this work was provided by the James Cook University Internal Research Grant CRT/2016/19. 


\section{Conflicts of Interest}

None declared.

\section{Multimedia Appendix 1}

Summary of evidence.

[PDF File (Adobe PDF File), 112KB-Multimedia Appendix 1]

\section{References}

1. Marsh A, Dale A, Willis L. A Counsellors Guide to Working with Alcohol and Drug Users. 2nd edition. Perth, Australia: Drug and Alcohol Office; 2007.

2. Cohn AM, Hunter-Reel D, Hagman BT, Mitchell J. Promoting behavior change from alcohol use through mobile technology: the future of ecological momentary assessment. Alcohol Clin Exp Res 2011 Dec;35(12):2209-2215 [FREE Full text] [doi: 10.1111/j.1530-0277.2011.01571.x] [Medline: 21689119]

3. Elliott JC, Carey KB, Bolles JR. Computer-based interventions for college drinking: a qualitative review. Addict Behav 2008 Aug;33(8):994-1005 [FREE Full text] [doi: 10.1016/j.addbeh.2008.03.006] [Medline: 18538484]

4. Pocuca N, Hides L, Zelenko O, Quek L, Stoyanov S, Tulloch K, et al. Initial prototype testing of Ray's Night Out: a new mobile app targeting risky drinking in young people. Comput Hum Behav 2016 Jan;54:207-214. [doi: 10.1016/j.chb.2015.07.033]

5. McMorris BJ, Hemphill SA, Toumbourou JW, Catalano RF, Patton GC. Prevalence of substance use and delinquent behavior in adolescents from Victoria, Australia and Washington State, United States. Health Educ Behav 2007 Aug;34(4):634-650. [doi: 10.1177/1090198106286272] [Medline: 16740513]

6. Botvin G, Griffin K. Life skills training: a competence enhancement approach to tobacco, alcohol,drug abuse. In: Scheier LM, editor. Handbook of Adolescent Drug Use Prevention: Research, Intervention Strategies, and Practice. Washington, DC: American Psychological Association; 2015:177-198.

7. Prochaska JO, Velicer WF. The transtheoretical model of health behavior change. Am J Health Promot 1997;12(1):38-48. [Medline: 10170434]

8. Arkowitz H, Miller W, Rollnick S. Motivational Interviewing in the Treatment of Psychological Problems. 2nd edition. New York, NY: Guilford Publications; 2015.

9. Oei TP, Lim B, Young RM. Cognitive processes and cognitive behavior therapy in the treatment of problem drinking. J Addict Dis 1991 Jul;10(3):63-80. [doi: 10.1300/J069v10n03 07] [Medline: 1932154]

10. Mattick RP, Jarvis T. A summary of recommendations for the management of alcohol problems: the quality assurance in the treatment of drug dependence project. Drug Alcohol Rev 1994 Jan;13(2):145-155. [doi: 10.1080/09595239400185221] [Medline: 16818402]

11. Burke BL, Arkowitz H, Menchola M. The efficacy of motivational interviewing: a meta-analysis of controlled clinical trials. J Consult Clin Psychol 2003 Oct;71(5):843-861. [doi: 10.1037/0022-006X.71.5.843] [Medline: 14516234]

12. Hansen WB, Raynor AE, Wolkenstein BH. Perceived personal immunity to the consequences of drinking alcohol: the relationship between behavior and perception. J Behav Med 1991 Jun;14(3):205-224. [Medline: 1875402]

13. Miller G. The smartphone psychology manifesto. Perspect Psychol Sci 2012 May;7(3):221-237 [FREE Full text] [doi: 10.1177/1745691612441215] [Medline: 26168460]

14. Larsen ME, Nicholas J, Christensen H. A systematic assessment of smartphone tools for suicide prevention. PLoS One 2016;11(4):e0152285 [FREE Full text] [doi: 10.1371/journal.pone.0152285] [Medline: 27073900]

15. Payne HE, Lister C, West JH, Bernhardt JM. Behavioral functionality of mobile apps in health interventions: a systematic review of the literature. JMIR Mhealth Uhealth 2015;3(1):e20 [FREE Full text] [doi: 10.2196/mhealth.3335] [Medline: 25803705]

16. Proudfoot J, Parker G, Hadzi PD, Manicavasagar V, Adler E, Whitton A. Community attitudes to the appropriation of mobile phones for monitoring and managing depression, anxiety, and stress. J Med Internet Res 2010;12(5):e64 [FREE Full text] [doi: 10.2196/jmir.1475] [Medline: 21169174]

17. Donker T, Petrie K, Proudfoot J, Clarke J, Birch M, Christensen H. Smartphones for smarter delivery of mental health programs: a systematic review. J Med Internet Res 2013;15(11):e247 [FREE Full text] [doi: 10.2196/jmir.2791] [Medline: $\underline{24240579]}$

18. Durnham DBT, Inc. iTunes Preview. Cupertino, CA: Apple Inc; 2013. DBT Diary Card \& Skills Coach URL: https://www. apple.com/itunes/ [accessed 2017-12-18] [WebCite Cache ID 6vnN7ORHt]

19. Rizvi SL, Dimeff LA, Skutch J, Carroll D, Linehan MM. A pilot study of the DBT coach: an interactive mobile phone application for individuals with borderline personality disorder and substance use disorder. Behav Ther 2011 Dec;42(4):589-600. [doi: 10.1016/j.beth.2011.01.003] [Medline: 22035988]

20. Grassi A, Gaggioli A, Riva G. New technologies to manage exam anxiety. Stud Health Technol Inform 2011;167:57-62. [Medline: 21685642] 
21. East ML, Havard BC. Mental health mobile apps: from infusion to diffusion in the mental health social system. JMIR Ment Health 2015;2(1):e10 [FREE Full text] [doi: 10.2196/mental.3954] [Medline: 26543907]

22. Australian Institute of Health and Welfare. 2013 National drug strategy household survey. 2014. URL: http://www. aihw.gov.au/WorkArea/DownloadAsset.aspx?id=60129549848 [accessed 2017-05-26] [WebCite Cache ID 6qkWa1oSo]

23. Gajecki M, Berman AH, Sinadinovic K, Rosendahl I, Andersson C. Mobile phone brief intervention applications for risky alcohol use among university students: a randomized controlled study. Addict Sci Clin Pract 2014;9:11 [FREE Full text] [doi: 10.1186/1940-0640-9-11] [Medline: 24985342]

24. Bendtsen M, Bendtsen P. Feasibility and user perception of a fully automated push-based multiple-session alcohol intervention for university students: randomized controlled trial. JMIR Mhealth Uhealth 2014;2(2):e30 [FREE Full text] [doi: 10.2196/mhealth.3233] [Medline: 25098296]

25. Thomas K, Linderoth C, Bendtsen M, Bendtsen P, Müssener U. Text message-based intervention targeting alcohol consumption among university students: findings from a formative development study. JMIR Mhealth Uhealth 2016 Oct 20;4(4):e119 [FREE Full text] [doi: 10.2196/mhealth.5863] [Medline: 27765732]

26. Weaver ER, Horyniak DR, Jenkinson R, Dietze P, Lim MS. "Let's get wasted!” and other apps: characteristics, acceptability, and use of alcohol-related smartphone applications. JMIR Mhealth Uhealth 2013;1(1):e9 [FREE Full text] [doi: 10.2196/mhealth.2709] [Medline: 25100681]

27. Crane D, Garnett C, Brown J, West R, Michie S. Behavior change techniques in popular alcohol reduction apps: content analysis. J Med Internet Res 2015;17(5):e118 [FREE Full text] [doi: 10.2196/jmir.4060] [Medline: 25977135]

28. Seko Y, Kidd S, Wiljer D, McKenzie K. Youth mental health interventions via mobile phones: a scoping review. Cyberpsychol Behav Soc Netw 2014 Sep;17(9):591-602. [doi: 10.1089/cyber.2014.0078] [Medline: 25007383]

29. Aguilera A, Muench F. There's an app for that: information technology applications for cognitive behavioral practitioners. Behav Ther (N Y N Y) 2012 Apr;35(4):65-73 [FREE Full text] [Medline: 25530659]

30. Lathia N, Pejovic V, Rachuri KK, Mascolo C, Musolesi M, Rentfrow PJ. Smartphones for large-scale behavior change interventions. IEEE Pervasive Comput 2013 Jul;12(3):66-73. [doi: 10.1109/MPRV.2013.56]

31. Wiechmann W, Kwan D, Bokarius A, Toohey SL. There's an app for that? Highlighting the difficulty in finding clinically relevant smartphone applications. West J Emerg Med 2016 Mar;17(2):191-194 [FREE Full text] [doi: 10.5811/westjem.2015.12.28781] [Medline: 26973750]

32. Beckjord E, Shiffman S. Background for real-time monitoring and intervention related to alcohol use. Alcohol Res 2014;36(1):9-18 [FREE Full text] [Medline: 26258996]

33. Hollis C, Falconer CJ, Martin JL, Whittington C, Stockton S, Glazebrook C, et al. Annual research review: digital health interventions for children and young people with mental health problems: a systematic and meta-review. J Child Psychol Psychiatry 2016 Dec 10;58(4):474-503. [doi: 10.1111/jcpp.12663] [Medline: 27943285]

34. Mellentin AI, Stenager E, Nielsen B, Nielsen AS, Yu F. A smarter pathway for delivering cue exposure therapy? The design and development of a smartphone app targeting alcohol use disorder. JMIR Mhealth Uhealth 2017 Jan 30;5(1):e5 [FREE Full text] [doi: 10.2196/mhealth.6500] [Medline: 28137701]

35. Ford JH, Alagoz E, Dinauer S, Johnson KA, Pe-Romashko K, Gustafson DH. Successful organizational strategies to sustain use of A-CHESS: a mobile intervention for individuals with alcohol use disorders. J Med Internet Res 2015 Aug 18;17(8):e201 [FREE Full text] [doi: 10.2196/jmir.3965] [Medline: 26286257]

36. Milward J, Khadjesari Z, Fincham-Campbell S, Deluca P, Watson R, Drummond C. User preferences for content, features, and style for an app to reduce harmful drinking in young adults: analysis of user feedback in app stores and focus group interviews. JMIR Mhealth Uhealth 2016 May 24;4(2):e47 [FREE Full text] [doi: 10.2196/mhealth.5242] [Medline: 27220371]

37. Suffoletto B, Kristan J, Person ML, Chung T, Clark DB. Optimizing a text message intervention to reduce heavy drinking in young adults: focus group findings. JMIR Mhealth Uhealth 2016 Jun 22;4(2):e73 [FREE Full text] [doi: 10.2196/mhealth.5330] [Medline: 27335099]

38. Garnett C, Crane D, West R, Brown J, Michie S. Identification of behavior change techniques and engagement strategies to design a smartphone app to reduce alcohol consumption using a formal consensus method. JMIR Mhealth Uhealth 2015;3(2):e73 [FREE Full text] [doi: 10.2196/mhealth.3895] [Medline: 26123578]

39. Donoghue K, Patton R, Phillips T, Deluca P, Drummond C. The effectiveness of electronic screening and brief intervention for reducing levels of alcohol consumption: a systematic review and meta-analysis. J Med Internet Res 2014;16(6):e142 [FREE Full text] [doi: 10.2196/jmir.3193] [Medline: 24892426]

40. Haug S, Schaub MP, Venzin V, Meyer C, John U, Gmel G. A pre-post study on the appropriateness and effectiveness of a Web- and text messaging-based intervention to reduce problem drinking in emerging adults. J Med Internet Res 2013;15(9):e196 [FREE Full text] [doi: 10.2196/jmir.2755] [Medline: 23999406]

41. Zucker RA, Gomberg ES. Etiology of alcoholism reconsidered. The case for a biopsychosocial process. Am Psychol 1986 Jul;41(7):783-793. [Medline: 3527004$]$

42. van Gemert GC, Dietze P, Gold J, Sacks-Davis R, Stoové M, Vally H, et al. The Australian national binge drinking campaign: campaign recognition among young people at a music festival who report risky drinking. BMC Public Health 2011 Jun 20;11:482 [FREE Full text] [doi: 10.1186/1471-2458-11-482] [Medline: 21689457] 
43. Choo CC, Harris KM, Chew PK, Ho RC. What predicts medical lethality of suicide attempts in Asian youths? Asian J Psychiatry 2017 Oct;29:136-141. [doi: 10.1016/j.ajp.2017.05.008]

44. Burns JM, Davenport TA, Durkin LA, Luscombe GM, Hickie IB. The internet as a setting for mental health service utilisation by young people. Med J Aust 2010 Jun 7;192(11 Suppl):S22-S26. [Medline: 20528703]

45. Farrer L, Gulliver A, Chan JKY, Batterham PJ, Reynolds J, Calear A, et al. Technology-based interventions for mental health in tertiary students: systematic review. J Med Internet Res 2013;15(5):e101 [FREE Full text] [doi: 10.2196/jmir.2639] [Medline: 23711740]

46. Kenny R, Dooley B, Fitzgerald A. Developing mental health mobile apps: exploring adolescents' perspectives. Health Informatics J 2014 Nov 10. [doi: 10.1177/1460458214555041] [Medline: 25385165]

47. Drum DJ, Denmark AB. Campus suicide prevention: bridging paradigms and forging partnerships. Harv Rev Psychiatry 2012;20(4):209-221. [doi: 10.3109/10673229.2012.712841] [Medline: 22894730]

48. Shand FL, Ridani R, Tighe J, Christensen H. The effectiveness of a suicide prevention app for indigenous Australian youths: study protocol for a randomized controlled trial. Trials 2013;14:396 [FREE Full text] [doi: 10.1186/1745-6215-14-396] [Medline: 24257410]

49. Zhang MW, Ho CS, Fang P, Lu Y, Ho RC. Usage of social media and smartphone application in assessment of physical and psychological well-being of individuals in times of a major air pollution crisis. JMIR Mhealth Uhealth 2014 Mar 25;2(1):e16 [FREE Full text] [doi: 10.2196/mhealth.2827] [Medline: 25098255]

50. Ho RC, Zhang MW, Ho CS, Pan F, Lu Y, Sharma VK. Impact of 2013 south Asian haze crisis: study of physical and psychological symptoms and perceived dangerousness of pollution level. BMC Psychiatry 2014 Mar 19;14:81 [FREE Full text] [doi: 10.1186/1471-244X-14-81] [Medline: 24642046]

51. Preziosa A, Grassi A, Gaggioli A, Riva G. Therapeutic applications of the mobile phone. Br J Guid Couns 2009 Aug;37(3):313-325. [doi: 10.1080/03069880902957031]

52. Kazemi DM, Cochran AR, Kelly JF, Cornelius JB, Belk C. Integrating mHealth mobile applications to reduce high risk drinking among underage students. Health Educ J 2013 Feb 19;73(3):262-273. [doi: 10.1177/0017896912471044]

53. Lu H, Frauendorfer D, Rabbi M, Mast M, Chittaranjan G, Campbell A, et al. StressSense: detecting stress in unconstrained acoustic environments using smartphones. New York, NY: ACM; 2012 Presented at: 2012 ACM Conference on Ubiquitous Computing; Sep 5-8, 2012; Pittsburgh, PA, USA.

54. Rachuri K, Musolesi M, Mascolo C, Rentfrow P, Longworth C, Aucinas A. EmotionSense: a mobile phones based adaptive platform for experimental social psychology research. New York, NY: ACM; 2010 Presented at: 2012 ACM Conference on Ubiquitous Computing; Sep 26-29, 2010; Copenhagen, Denmark.

55. Reger MA, Gahm GA. A meta-analysis of the effects of internet- and computer-based cognitive-behavioral treatments for anxiety. J Clin Psychol 2009 Jan;65(1):53-75. [doi: 10.1002/jclp.20536] [Medline: 19051274]

56. Strickland. Smartphone app keeps watch over schizophrenic patients: monitoring behavioural patterns can predict a relapse. 2015. URL: http://spectrum.ieee.org/biomedical/diagnostics/smartphone-app-keeps-watch-over-schizophrenic-patients [accessed 2017-05-26] [WebCite Cache ID 6qkTA0FJq]

57. Wayne N, Ritvo P. Smartphone-enabled health coach intervention for people with diabetes from a modest socioeconomic strata community: single-arm longitudinal feasibility study. J Med Internet Res 2014;16(6):e149 [FREE Full text] [doi: 10.2196/jmir.3180] [Medline: 24907918]

58. Harrison V, Proudfoot J, Wee PP, Parker G, Pavlovic DH, Manicavasagar V. Mobile mental health: review of the emerging field and proof of concept study. J Ment Health 2011 Dec;20(6):509-524. [doi: 10.3109/09638237.2011.608746] [Medline: 21988230]

59. Aguilera A, Muñoz RF. Text messaging as an adjunct to CBT in low-income populations: a usability and feasibility pilot study. Prof Psychol Res Pr 2011 Dec 01;42(6):472-478 [FREE Full text] [doi: 10.1037/a0025499] [Medline: 25525292]

60. Kuhn E, Greene C, Hoffman J, Nguyen T, Wald L, Schmidt J, et al. Preliminary evaluation of PTSD Coach, a smartphone app for post-traumatic stress symptoms. Mil Med 2014 Jan;179(1):12-18. [doi: 10.7205/MILMED-D-13-00271] [Medline: 24402979]

61. Turner-McGrievy G, Tate D. Tweets, apps, and pods: results of the 6-month mobile pounds off digitally (Mobile POD) randomized weight-loss intervention among adults. J Med Internet Res 2011;13(4):e120 [FREE Full text] [doi: 10.2196/jmir.1841] [Medline: 22186428]

62. Mattila E, Orsama A, Ahtinen A, Hopsu L, Leino T, Korhonen I. Personal health technologies in employee health promotion: usage activity, usefulness, and health-related outcomes in a 1-year randomized controlled trial. JMIR Mhealth Uhealth 2013;1(2):e16 [FREE Full text] [doi: 10.2196/mhealth.2557] [Medline: 25098385]

63. Kuhn E, Eftekhari A, Hoffman JE, Crowley JJ, Ramsey KM, Reger GM, et al. Clinician perceptions of using a smartphone app with prolonged exposure therapy. Adm Policy Ment Health 2014 Nov;41(6):800-807. [doi: 10.1007/s10488-013-0532-2] [Medline: 24398700]

64. Cafazzo JA, Casselman M, Hamming N, Katzman DK, Palmert MR. Design of an mHealth app for the self-management of adolescent type 1 diabetes: a pilot study. J Med Internet Res 2012;14(3):e70 [FREE Full text] [doi: 10.2196/jmir.2058] [Medline: 22564332] 
65. Myrecek. AlcoDroid Alcohol Tracker. 2015. URL: https://play.google.com/store/apps/details?id=org.M.alcodroid [accessed 2017-12-28] [WebCite Cache ID 6w3x0i2DF]

66. Zhang M. Alcohol Tracker. 2015. URL: https://play.google.com/store/apps/details?id=com.melvynwbzhang.alcohol [accessed 2017-12-28] [WebCite Cache ID 6w3y0yHmi]

67. CityJams. Blood Alcohol Calculator. 2013. URL: $\underline{\text { https://www.slappme.com [accessed 2017-12-29] [WebCite Cache ID }}$ 6w3vvtOak]

68. R U Buzzed?. 2009. URL: https://play.google.com/store/apps/details?id=com.cdot.rubuzzed2\&hl=en [accessed 2018-01-11] [WebCite Cache ID 6wOU2nVJi]

69. Wichmann R. IntelliDrink-Blood Alcohol Content Calculator (Version 2.0). 2015. URL: https://itunes.apple.com/us/app/ intellidrink-pro-blood-alcohol-content-bac-calculator/id440759306? $\mathrm{mt}=8$ [accessed 2017-12-28] [WebCite Cache ID 6w3yTN4Ii]

70. GoFirst. 2011. SoberApp, alcohol calculator. URL: https://play.google.com/store/apps/details?id=sober.app\&hl=en [accessed 2018-01-11] [WebCite Cache ID 6wOUuzf6L]

71. Cole-Lewis H, Kershaw T. Text messaging as a tool for behavior change in disease prevention and management. Epidemiol Rev 2010;32:56-69 [FREE Full text] [doi: 10.1093/epirev/mxq004] [Medline: 20354039]

72. Muench F, Weiss RA, Kuerbis A, Morgenstern J. Developing a theory driven text messaging intervention for addiction care with user driven content. Psychol Addict Behav 2013 Mar;27(1):315-321 [FREE Full text] [doi: 10.1037/a0029963] [Medline: 22963375]

73. Mac Sithigh D. App law within: rights and regulation in the smartphone age. Int J Law Inf Technol 2013 Mar 01;21(2):154-186. [doi: 10.1093/ijlit/eat002]

74. Sutton M, Fraser M. Smartphone apps: the rise of smartphone health and medical apps. Aust Life Sci 2013;10(2):36-37.

75. Lim MS, Vella A, Sacks-Davis R, Hellard ME. Young people's comfort receiving sexual health information via social media and other sources. Int J STD AIDS 2014 Dec;25(14):1003-1008. [doi: 10.1177/0956462414527264] [Medline: 24616114]

76. Luxton DD, McCann RA, Bush NE, Mishkind MC, Reger GM. mHealth for mental health: integrating smartphone technology in behavioral healthcare. Prof Psychol Res Pract 2011;42(6):505-512. [doi: 10.1037/a0024485]

77. Clar C, Dyakova M, Curtis K, Dawson C, Donnelly P, Knifton L, et al. Just telling and selling: current limitations in the use of digital media in public health: a scoping review. Public Health 2014 Dec;128(12):1066-1075. [doi:

10.1016/j.puhe.2014.09.009] [Medline: 25443388]

78. Gardner H, Davis K. The App Generation: How Today's Youth Navigate Identity, Intimacy, and Imagination in a Digital World. New Haven, CT: Yale University Press; 2013.

79. Williams P. Alcohol related social disorder and rural youth. 1999. URL: http://www.aic.gov.au/media library/publications/ tandi pdf/tandi140.pdf [accessed 2018-01-11] [WebCite Cache ID 6qkVmQIWZ]

80. Teesson M, Hall W, Slade T, Mills K, Grove R, Mewton L, et al. Prevalence and correlates of DSM-IV alcohol abuse and dependence in Australia: findings of the 2007 National Survey of Mental Health and Wellbeing. Addiction 2010 Dec;105(12):2085-2094. [doi: 10.1111/j.1360-0443.2010.03096.x] [Medline: 20707771]

Edited by G Eysenbach; submitted 17.10.16; peer-reviewed by L Panicker, B Dooley; comments to author 21.01.17; revised version received 07.06.17; accepted 09.10.17; published 13.02.18

Please cite as:

Choo CC, Burton AAD

Mobile Phone Apps for Behavioral Interventions for At-Risk Drinkers in Australia: Literature Review

JMIR Mhealth Uhealth 2018;6(2):e18

URL: https://mhealth.jmir.org/2018/2/e18/

doi: $10.2196 /$ mhealth. 6832

PMID: 29439946

(C) Carol C Choo, André A D Burton. Originally published in JMIR Mhealth and Uhealth (http://mhealth.jmir.org), 13.02.2018. This is an open-access article distributed under the terms of the Creative Commons Attribution License (https://creativecommons.org/licenses/by/4.0/), which permits unrestricted use, distribution, and reproduction in any medium, provided the original work, first published in JMIR mhealth and uhealth, is properly cited. The complete bibliographic information, a link to the original publication on http://mhealth.jmir.org/, as well as this copyright and license information must be included. 